\title{
SMALL TOWNS IN SERBIA - THE “BRIDGE” BETWEEN THE URBAN AND THE RURAL
}

Marko Filipović, Vlasta Kokotović Kanazir, Marija Drobnjaković ${ }^{1}$

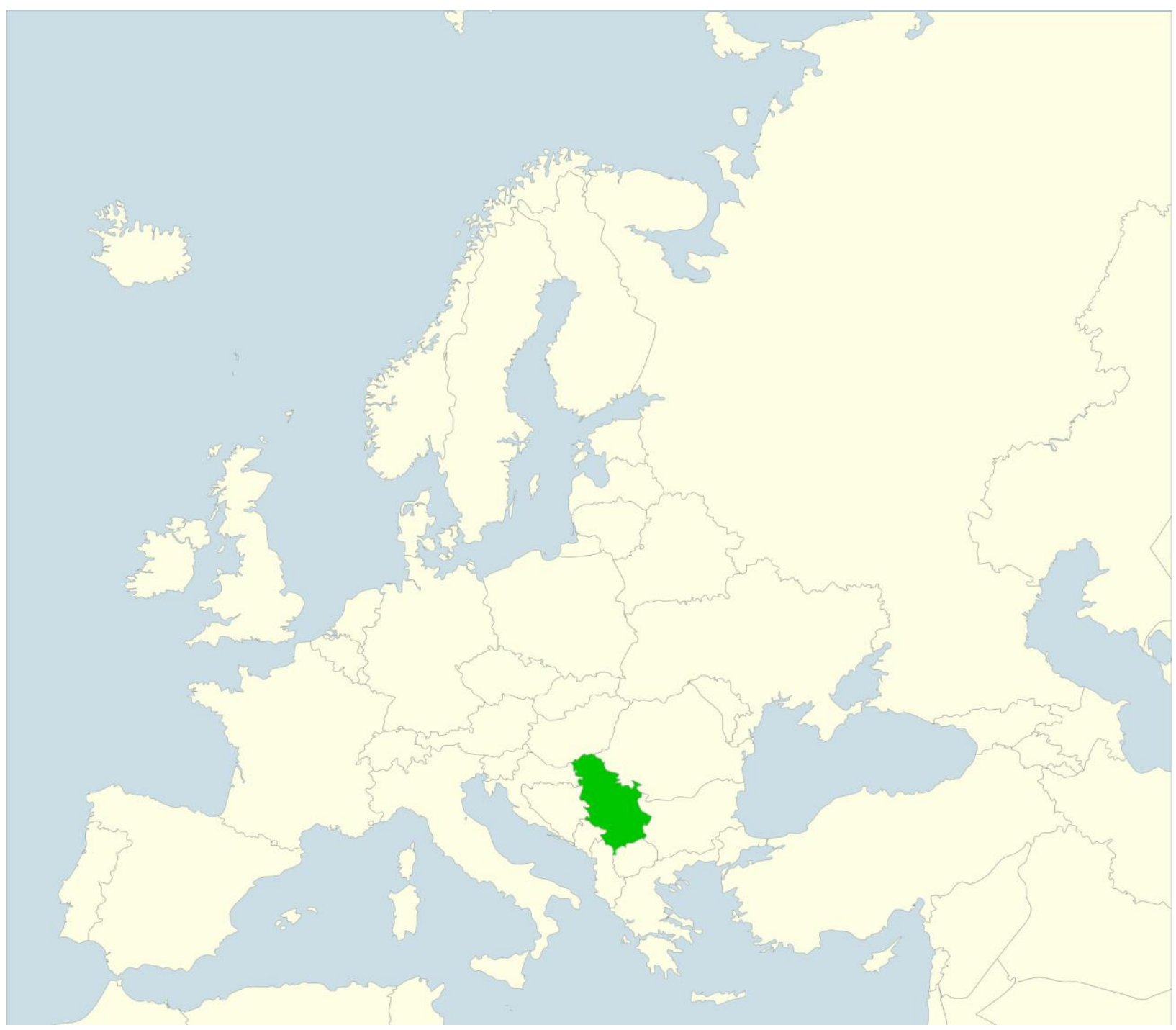

${ }^{1}$ MSc Filipović Marko, ResearchAssociate MSc, Kokotović Kanazir Vlasta Research Associate, MSc Drobnjaković Marija (corresponding author) ResearchAssociate Geographical Institute "Jovan Cvijić", Serbian Academy of Science and Arts, Belgrade; e-mails: m.filipovic@gi.sanu.ac.rs; v.kokotovic@gi.sanu.ac.rs; m.drobnjakovic@gi.sanu.ac.rs 


\begin{abstract}
The study presented in this paper deals with the definition and role of small towns in the spatial development of the Republic of Serbia. An analysis of the profiles of small towns was performed and they were compared based on their spatial and population characteristics. The aim of this study is to determine the role of small towns in the development of settlement networks and the balanced population development of a country as a whole by identifying their specific features and establishing a ranking of their importance in local and regional contexts.
\end{abstract}

Key words: urban settlement, small town, role, Serbia

\begin{abstract}
Abstrakt: Istraživanje u ovom radu odnosi se na problematiku malih gradova, njihovog definisanja i uloge u prostornom razvoju Republike Srbije. Izvršena je analiza I komparacija profila malih gradova kroz njihove prostorne i demografske karakteristike. Cilj rada je da odredi ulogu malih gradova u razvoju mreže naselja, kao i uravnoteženom populacionom razvoju zemlje, kroz sagledavanje njihovih specifičnosti i gradaciju značaja u lokalnim I regionalnim okvirima.
\end{abstract}

Ključne reči: gradska naselja, mali gradovi, uloga, Srbija

\title{
1. Introduction
}

Small towns, their relationship with rural areas, distance from, and the relationship to larger urban centers, are topical issues in scholarly literature in Serbia. Numerous studies have been conducted on this subject, but all of them have emphasized the effects of social and economic causes of the transformation and development of urban settlements. The concept of small towns is not strictly defined. There are numerous discussions regarding their population size and functional significance. Therefore, the aim of this paper is to establish the role of small towns in Serbia in the process of the integration of urban and rural areas according to their demographic potential for the country's regional and balanced spatial development. In this paper, the term 'small town' is used to designate all urban settlements with less than 20,000 inhabitants, based on statistical and legislative criteria, according to the methodology used by the Statistical Office of the Republic of Serbia, without questioning whether their status of urban settlements is justified or not.

An overview of available scholarly literature leads to the conclusion that small towns were not a common and frequent research subject and topic of scientific discussions. In an international context, there is a noticeable majority of papers with a focus on big cities, in recent time metropolises, conurbations, etc. It seems that in a way the study of small towns has been neglected due to the growing attention paid to the study of large citiess. The focus of recent research into small towns is related to their role in the economic, social and spatial development on the regional and national levels, but also regarding the strategic vision and their role in connecting rural environments and local communities (Bandaranaike, Kenyon \& Black, 2001; Pirisi \& Trócsányi, 2007; ESPON, 2006).

\section{Distinguishing between urban and rural settlements in Serbia}

The problem of distinguishing among settlement types in Serbia is an attractive and topical issue that is still the subject of an open academic discussion and harmonization. The authors believe that it is necessary to give an overview in terms of defining and determining urban settlements in general, and then define small towns.

The official classification of settlements in Serbia is based on the urban-rural dichotomy. In distinguishing between urban and rural areas, the focus is placed on urban areas. Rural areas are treated as a residual to urban ones. In Serbian scholarly literature, numerous examples of adequate typologies of settlements are given (Cvijić, 2000; Macura, 1954; Radovanović, 1970; 
Bukurov, 1980; Stamenković \& Bačević, 1992; Veljković, Jovanović \&Tošić, 1995; Tošić, B. 1996; Tošić, D., 1999; Petovar, 2007; Pavkov, 2008). The model that has most commonly been used in practice for the classification of settlements is derived from the official national statistics. According to this model, urban settlements are strictly defined, and those that do not meet the criteria are classified into the other group, as rural settlements. However, this division has been treated variously depending on the basic census model.

Since 1981, the determination of urban settlements was the responsibility of local authorities. According to the Law on Construction Land (Official Gazette No. 31/79), the urban character of settlements was determined by the Municipal Assembly. Settlements that had an adopted urban plan were granted the administrative status of towns. During this period, major changes regarding the administrative status of settlements were observed. Many municipal centers became urban settlements. Some smaller centers acquired an urban character thanks to the development of specific functions (Zlatibor, Divčibare and spa resorts). In some cases, the "legislative" classification proved to be one-sided and inaccurate. Furthermore, some settlements with a distinctly urban character, a large population and functional capacity, remained in the group of other settlements. On the other hand, some settlements included in the urban group (Pećani and Rucka in Belgrade region) had less than 500 inhabitants, but their urban morphological features were indistinguishable from the neighboring rural settlements. The group of other settlements, according to the current distinction, includes municipal centers and traditional varošice (boroughs). We assume that the authors of this division expected that the local governments would grant an urban status only to those settlements that represented, by their functionality and other characteristics, a really urban type of settlement. The Statistical Office tracked these changes and applied them in its own classification. The experiences of scholars and other users of statistics indicate that the current distinction between urban and rural settlements does not meet the needs and does not correspond to the reality.

A novelty in the administrative definition of cities and towns on the territory of the Republic of Serbia was introduced by the Law on Territorial Organization, as of 2007. The status of a city was granted to those territorial units which were economic, administrative, geographical and cultural centers of a wider area, with more than 100,000 inhabitants. In this way, several individual local government units that had previously been municipalities became cities in a legal sense. Some territorial units were granted the status of cities due to specific economic, geographic or historical reasons, though their population was smaller than defined. This legaladministrative concept of a city should not be confused with the concept of an urban settlement (in urban morphological and functional terms) as a more complex type of settlement of a greater spatial and functional significance defined by relevant criteria (SPRS, 2010).

Accordingly, it is necessary to redefine the settlement, as a concept, to choose relevant criteria and make a precise distinction between urban and rural settlements and their transitional forms.

\section{Definition of small towns in Serbia}

In Serbia, there is still no generally accepted and unique definition of small towns. A review of the available literature suggests that small-sized towns have not been a frequent subject of research and scholarly discussion. Even in the international context, studies related to big cities and, in recent times metropolises, urban agglomerations, etc. apparently prevail over those dealing with small towns Due to the growing attention paid to the study of large cities, mediumsized and small towns are relatively neglected or even ignored both by international organizations dealing with this issue and academic circles. Urban studies have also been mainly focused on big cities or even just the metropolises. The statistical and informational material available at the European level is scarce and is not conceptually comparable, as demonstrated by the results of the ESPON 1.4.1 project "The Role of Small and Medium-Sized Towns". This is a recent document that deals with the role of small and medium-sized towns in some European national urban systems.

In European countries, small towns range from settlements with a few hundred inhabitants to those with more than 40 thousand people. The population size of a town is not a determining 
criterion for the concept of the small town. The experience of other countries shows that in Germany, for example, the lower population limit for big cities is 100,000 inhabitants, while medium-sized towns have a population between 20,000 and 100,000, and the only difference in defining small towns is the lower population limit - 5,000 inhabitants. In Russia, the upper population limit for the category of small towns is 5,000 inhabitants, while in France, the upper limit for the category of medium-sized towns is 200,000 inhabitants (Spasić, Petrić, Filipović, 2007). In Central European countries, rural areas are micro-regions that usually include a small town, which provides basic economic, social, cultural services, and surrounding villages.

In Serbia, there is neither clear definition of the "small town" nor a precise categorization of urban settlements. According to Marjanović-Uzelac (1999), a small town is an urban agglomeration that meets the minimum requirements in terms of population, that has reduced the primary sector activities within the urban corps, and that has a minimal influence on its surroundings. This issue was addressed by several authors who sought to classify urban areas, mainly on the basis of their population size (Vogelnik, 1961; Kojić, 1973; Spasić, 1984; Stamenković, 2004; Živanović, 2012). These studies show that the lower population limit for small towns has been variously determined. According to them, small towns usually include settlements with more than 2,000 inhabitants, or even 10,000 inhabitants. However, some authors combine demographic and functional criteria, or observe the role and importance of individual urban centers in the settlement network, while others set the upper threshold for small urban settlements or associate their determination with the administrative status of the settlement ${ }^{2}$.

Branislav Kojić (1973) presented perhaps the most complete classification of urban settlements in Serbia. He offered a precise definition of individual categories, as well as a projection of their future development (rural small town, small town, town, city, big city). The population size explicitly determines the category to which a town (settlement) belongs but there is a certain population range corresponding to each category. Basic functions also determine the rank of each settlement.

This paper deals with urban settlements that belong to the category of small towns, designated in accordance with the official statistical division of settlements and the upper threshold population size of 20,000 residents. It is presumed that the spatial and functional organization of the settlement network in Serbia is dominated by small towns. Namely, out of the total number of urban settlements in Serbia (168), 51 have less than 5,000 inhabitants, 41 have a population of 5,000 - 10,000 inhabitants and 34 have 10,000 - 20,000 inhabitants. In 25 municipalities in Serbia (excluding Kosovo and Metohija) there are no urban settlements. This means that according to the demographic size (demographic criteria), 126 small urban settlements in Serbia may be classified as small towns. According to many modern theorists, small towns offer the highest "quality of life" because of their comparative advantages over other towns (Stojanović, 1984). Small towns are important because in many cases they are administrative, economic and cultural centers of the municipality. One of the important aspects of this type of settlements is their influence on their rural surroundings. Within the local territory of small urban settlements, significant differences in the intensity and scope of integration and relations with the surrounding rural area have been observed. Special attention is paid to small towns which are also municipal centers, in which a centralized type of functional organization, distribution of public services and population concentration is substantially expressed. Because of that, although they act as urban poles in rural areas (OECD, 1994), their role is crucial in achieving a balanced socio-economic and population development of a region and a country. In this way, they are an essential instrument of polycentric development. The differences among small towns are observed in the size and structure of their population, as well as in their functions. The towns that have a higher degree of economic and social development - in other words, those with industrialized urban functions, have a more pronounced impact on their immediate surroundings, and vice versa (Spasić, 1984).

\footnotetext{
2 Small towns are municipal centers or complementary municipal centers, and they are rarely subregional centers. Medium-sized towns are regional or subregional centers, potentially big towns; in functional terms they have a superregional character (Spasić, 1984).
} 
There are economically developed towns with a small population. They often have a leading industry or are located in the vicinity of major cities with a strong economic function. Some towns with a population greater than 20,000 are identified as small towns because they share other features with small towns. Although it is difficult to identify all of the diverse characteristics that define small towns, there are a number of indicators that, taken together, identify their institutional and management characteristics of a small town (Bulgarian strategy of small cities, 2003).

The vision of the spatial development of the Republic of Serbia suggests a greater degree of territorial cohesion, which would be achieved by the policy of decentralization and polycentricism. With regard to demographic predispositions, small towns are still in a better position and can be considered as centers of demographic revitalization. The policy of polycentrism is a way to solve problems related to a strong polarization of demographic development on the local and regional levels relying on the functional connectivity between towns and their rural surroundings in the region (SPRS, 2010). In the process of establishing a balanced and polycentric development of Serbia, as a spatial unit that is harmonized and integrated in terms of the socio-economic situation and population, an important role is played by small towns. In this respect, they act as a spatial and developmental bridge between marginalized and underdeveloped rural areas and urban poles, i.e. as functional and population nodes.

\section{Methodology}

In the present study, the authors have consulted previous research in this area (Kojić, 1973; Bukurov 1980, Spasić, 1984; SORS), which has been the basis for identifying a group of urban settlements that represent small towns. The term 'small town' is used for all urban settlements with less than 20,000 inhabitants, which have this status on the grounds of statistical and legislative criteria, according to the methodology used by the Statistical Office of the Republic of Serbia. According to the 2011 Census, 126 settlements have been identified as small towns. The analysis was conducted in Central Serbia ${ }^{3}$, based on the statistical data from the 2011 Census (SORS, 2012a, 2012b, 2012c); for the purpose of calculating the population change index, data from the 2002 Census were used.

The methodology presented in the paper focuses on the demographic situation in small urban settlements. The evaluation of demographic conditions allows us to determine the real position of small towns in the settlement network (Kokotović, Spalević, 2014). In order to perform a demographic evaluation of settlements and get a comprehensive insight into the demographic situation and processes in the observed area, it is necessary to simultaneously compare multiple indicators. Their cause-and-effect relationship provides an opportunity to observe the demographic profile of small towns. Having this in mind, the authors used the method of settlement valorization (Grugurević, 1995; 2001) or, in other words, the quantitative evaluation of the demographic situation in small towns. The above-mentioned methodology was modified by a set of indicators that were applied.

The evaluation was performed on the basis of a comparison of five indicators: population number, population change index ${ }^{4}$, which shows the population increase or decrease in the $2002-2011$ period; the share of people aged $0-19^{5}$; the share of the employed population, as a indicator of the local population's activity; and total daily commuters (workers, pupils and students). These demographic indicators reflect fairly well the quantitative and dynamic

\footnotetext{
3 The province of Kosovo and Metohija was excluded because of the insufficient official information.

${ }^{4}$ Population change index - the value of the population change index greater than 100 indicates population increase in an intercensus period, whereas values lower than 100 indicate population decrease.

5 The 0 - 19 age group represents youth, but there are differences between Serbian scholarly studies and the official statistical documents regarding the upper age threshold. According to some authors, the young population group includes children up to 14 years of age, while others opt in favor of the age of 19 as the age threshold. Also, this upper threshold changed over time in official statistics and documents. The authors use the 0 - 19 age group as a relevant indicator in this research.
} 
characteristics of demographic processes in small towns, as well as the socio-economic features of the chosen settlements. They are especially important for understanding the relationships among the settlements and their role in spatial development. The authors believe that an adequate and scientifically objective valorization of the chosen indicators can reveal demographic strengths or weakness of small towns (including population trends, age structure, economic activity and daily mobility), as well as that it could be used as a platform for establishing their role in the demographic and regional development.

Small towns are ranked based on the values of the observed indicators. The number of ranks is equal to the number of elements in the sample - in this particular case, the number of analyzed small towns. According to the values of indicators, the rank of small towns was established based on the favorability of local conditions for demographic and regional development. Unfavorable demographic characteristics were assigned rank 126, while the most favorable ones were assigned rank 1 (Annex). Using a quantitative method, the position, or rank for each settlement and for each of the five indicators (expressed in numbers from 1 to 126) was determined in the following manner:

- the total population - the small town with the largest population size was assigned rank 1 , whereas the settlement with the smallest number of residents was assigned rank 126;

- the population change index - the settlement with the maximum index was given rank 1 , whereas the small town with a minimum index was given rank 126;

- the share of the population aged 0 - 19 - the small town with the largest share of this age group was given rank 1, whereas the settlement with the smallest share was given rank 126 ;

- the share of the employed population - rank 1 was assigned to the settlement with the largest and rank 126 was assigned to the settlement with the smallest share of the employed population;

- the share of total daily commuters in the total population - rank 1 was assigned to the settlement with the largest share of daily commuters and rank 126 to the settlement with the smallest share of daily commuters ${ }^{6}$.

The ranking of small towns according to these indicators was the basis for applying the method of the cumulative sum of ranks in order to obtain a complete picture of the demographic situation in each small town, as well as its position within the settlement network. In the quantitative procedure, the number of categories was equal to the number of small towns, and the number of points assigned to each settlement was equal to its rank. In the final stage, small towns were sorted from the highest to the lowest rank, which also reflected the hierarchical relationship of the settlements. The grouping of demographically and functionally similar small towns was done on the basis of the cumulative value of the sum of ranks (Annex). Five groups of small town were identified: very favorable, favorable, moderate, unfavorable and extremely unfavorable. Generally speaking, these groups represent the demographic situation in small towns and their capacity for a balanced regional and population development.

After the ranking, settlements were grouped according to similar demographic conditions for the development of small towns. For the purpose of analysis and in order to obtain a detailed overview of indicators that are dominant in the ranking of settlements, a qualitative method was applied - another method based on the evaluation of indicators (Table 1). Each of the five indicators was assessed on a scale from 1 to 5 . These degrees represent the level of favorableness of the observed demographic features. Higher degrees indicate favorable conditions, whereas lower degrees indicate an unfavorable demographic situation for

\footnotetext{
${ }^{6}$ Higher ranking is given to settlements with a greater share of daily commuters in the total population, as there is an assumption that the share of daily commuters is determined by the available infrastructure and facilities. Therefore, the accessibility is a precondition for the creation of stronger links between urban and rural spaces.
} 
the development of small town. That was the research platform for the evaluation of factors that determined the demographic profile of small towns.

Tab 1. Methodology of evaluating demographic features. Source: Elaborated by authors

\begin{tabular}{|l|c|c|c|c|c|}
\hline Indicator/value & 1 & 2 & 3 & 4 & 5 \\
\hline Population size & $<2000$ & $2001-5000$ & $5001-10000$ & $10001-15000$ & $15001-20000$ \\
\hline Index of population change & $<70$ & $71-80$ & $81-90$ & $91-100$ & $>101$ \\
\hline Youth (0-19) and elderly (+65) [\%] & $\mathrm{Y}<20$ & $\mathrm{Y}<25$ & $\mathrm{Y}<25$ & $\mathrm{Y}>25$ & $\mathrm{Y}>25$ \\
\hline & $\mathrm{E}>15$ & $\mathrm{E}>12$ & $\mathrm{E}<12$ & $\mathrm{E}>8$ & $\mathrm{E}<8$ \\
\hline Employed population & $<20$ & $21-25$ & $26-30$ & $31-39$ & $>40$ \\
\hline Daily migration [\%] & $<10$ & $11 \_20$ & $21-50$ & $51-75$ & $>76$ \\
\hline
\end{tabular}

\section{Results}

In order to provide a better insight into development opportunities and determine differences in the group of small towns, the authors primarily present the factors that have influenced their formation and evolution. The overview of the development of the network of small towns explains their current and expected role as a bridge between rural areas and highly developed urban entities.

\section{Development of small towns in a spatial and temporal perspective}

The formation and genesis of settlements on the territory of the Republic of Serbia have been affected by a set of different factors: first of all, natural conditions, historical circumstances and advanced functions in the settlement. However, the course of the evolution of settlements was not the same in all parts of Serbia. Significant regional differences are obvious. The morphology of the terrain, orohydrographical features and architectural tradition have determined the planned development of the settlement network in Serbia's northern province - Vojvodina. A network of urban settlements has been developing in Vojvodina since the establishment of the first real settlement network in this area, in the $15^{\text {th }}$ century, due to colonization, economic development and the construction of transport networks in the $19^{\text {th }}$ century (Bukurov, 1983).On the other hand, in Serbia, to the south of the Sava and Danube rivers, there is a whole mosaic of morphological and functional types, whose formation and evolution were crucially determined by the natural features of the terrain, the historical development of the area, political events, shifts of cultures and civilizations and ethnographic events (Cvijić, 2000). In river valleys and along traffic axes, a dense network of rather large settlements was formed, with noticeable differences in the eastern and western parts of the country, figuratively divided by the natural direction of the meridian line formed by mountain ranges (Kojić, 1970; Kojić \& Simonović, 1971). The majority of modern small towns developed from the mid-20 ${ }^{\text {th }}$ Century towns and varoši. These traditional varoši form the category of functionally undetermined, undeveloped, economically unjustified and demographically small settlements, which are in the middle of the settlement system in terms of the importance of their functions. Functional features were used for their evaluation and classification (Đorđević, 1924, Kojić, 1973). The extent of their functions is manifest in their immediate vicinity, putting their development and existence in a direct relationship with the surrounding rural population. Accordingly, by the end of the $20^{\text {th }}$ century, they constituted an important link between urban and rural areas.

During the formation of the system of small urban settlements in Serbia a significant role was played by industrialization and the transition from primary to secondary business activities, which caused migration from rural to urban areas. Today, judging by their developmental characteristics, small towns are a very important link that contributes to a balanced development of the area. Incentives for development are received from larger towns and they are further transferred to the areas surrounding small towns. Small towns, which are classified as urban settlements according to administrative criteria and small urban settlements according to population size are a heterogeneous group in a regional, socio-economic and demographic 
sense. Differences between them exist in terms of status, functional, demographic and urban morphological features. Accordingly, this group includes settlements ranging from towns that have the capacity for the administrative role as municipal centers, through those which act as sub-regional centers, to towns with economic development functions, such as spa centers (Vrnjačka Banja, Sokobanja, Banja Koviljača, Vranjska Banja, Niška Banja), tourist settlements (Zlatibor, Guča, Divčibare) and towns with industrial and mining functions (Majdanpek, Kostolac, Sevojno, Veliki Crljeni, Resavica, Aleksinački Rudnik). A common feature of small urban centers is their function as a municipal center or center of secondary importance, as well as a direct contact with the rural environment. During the 1960s and the 1970s, small urban settlements were the immediate centers of urbanization. For this reason, the issue of the development potential of small towns in Serbia is topical, and the study of their demographic potential, the assessment of future demographic trends and future population movements in them are important.

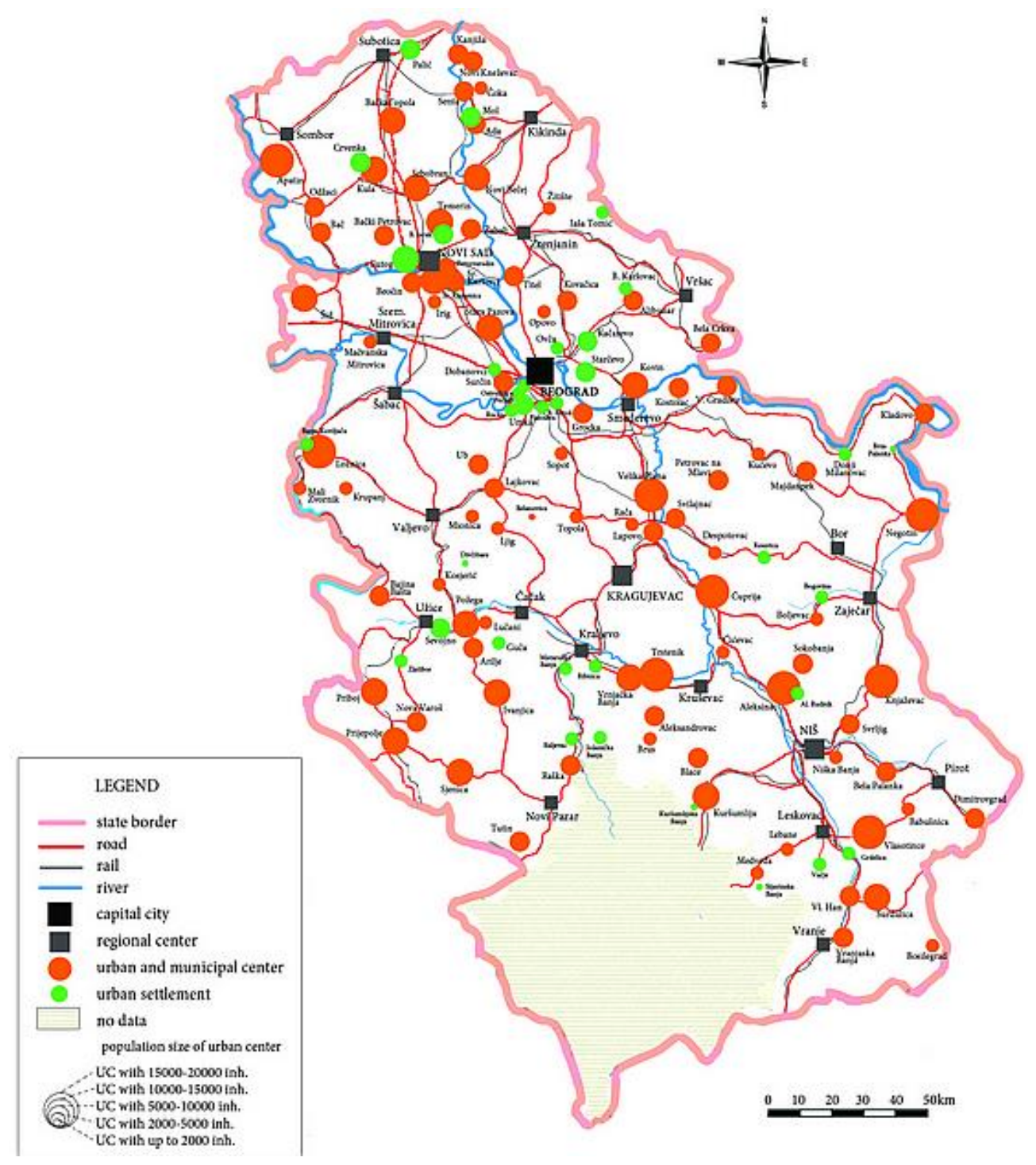

Fig 1. Spatial distribution of small towns in Serbia.

The role of small towns, their functions and the proximity of major urban centers have had an impact on their population size and spatial distribution. There is an imbalance in Serbian terms between the spatial and socio-economic development of small towns (Figure 1). A denser network of small towns is observable in Vojvodina, in northern part of Serbia, where satellite settlements around regional centers have a distinct role, while following the centers' development in demographic and economic terms. In terms of structure and evolution they are completely different from cities in Central Serbia. These settlements were formed and 
developed in a planned manner; they have a favorable topography and traffic accessibility; and the development of their business sector was even and parallel to the major centers. They act as a counterbalance to big cities and a viable link with the agrarian hinterland.

However, in the orographically and socio-economically heterogeneous area of Central Serbia there is a mosaic of small town types. Their role and size are determined by the multitude of various factors. Their common feature is that they have developed along major traffic routes (Figure 1). Only a few settlements are located outside these development axes and their position acted as the initial development barrier. Some small urban settlements are located near regional centers, so they gradually acquire the functional role of dependent settlements developing totally or partially in the 'shadow' of regional centers (Svrljig, Požega, etc.). On the other hand, other urban areas with a small population and specific functions took shape near small towns. These include the service-type settlements (spa/health resorts, mountain tourist centers, traffic centers - Lapovo) or those predominantly oriented towards secondary industry (mining settlements - Aleksinački Rudnik, Resavica, Majdanpek, Kostolac; industrial settlements - Sevojno, Trstenik, etc.). They have a crucial role in the sustainable rural, balanced socio-economic and polycentric spatial development of Central Serbia. By diminishing the importance of small towns in this region the connection between rural areas - peripheral in terms of position, agrarian and neglected in economic terms and marginalized in the social sense - and the urban poles of population and functional concentration, was lost.

The demographic development of small towns reflects the complex changes in population trends during the second half of the $20^{\text {th }}$ century. The overall socio-economic situation and development advantages or limitations have influenced the development of these towns and have contributed to their faster or slower evolution. The above-mentioned conditions have had an impact on the change in the size categories of small towns (Tab 1). Their fastest growth was recorded in the 1961 - 1971 period, as a result of intensive migration from rural to urban areas. Previous research (Stojanović, Vojković, 2005, Rančić, 1984 - 1985) has shown that at the beginning of the 1970s the focus of major demographic processes shifted from the rural to the urban population. In this period, the number of small towns reached a maximum. After 1991, the number of small towns has gradually decreased. The demographically smallest settlements particularly grew in number. This was accompanied with a parallel process of their demographic growth (the growth of settlements with more than 5,000 inhabitants). The increase in the number of residents in small towns in the reporting period was determined by the scope of natural increase and the migration balance. On the other hand, these two phenomena depend on a number of elements, i.e. demographic phenomena (age, gender, marital structure) and socio-economic developments (Ginić, 1967). Permanent migration has also had a very significant impact on population trends in small towns. Their position in the hierarchy of settlements has caused this to be the first step in the permanent relocation of the rural population. Therefore, unlike in other categories of towns, the influx of in-migrants has come from migrants from the territory of the same municipality (Filipović \& Đurđević, 2007). After the decline of rural demographic resources (Stojanović \& Vojković, 2005, Kokotović, Filipović \& Magdalenić, 2016), migration flows to major cities gained in importance; accordingly, a large number of small towns have become a source of out-migration.

Tab 2. Number of small towns according to population size, in the period 1961 - 2011. Source: Statistical Office of the Republic of Serbia (SORS, 2011a)

\begin{tabular}{|l|c|c|c|c|c|c|}
\hline Population size / Census & 1961 & 1971 & 1981 & 1991 & 2002 & 2011 \\
\hline up to 2.000 & 34 & 22 & 16 & 15 & 15 & 16 \\
\hline $2.001-5.000$ & 50 & 39 & 36 & 34 & 33 & 34 \\
\hline $5.001-10.000$ & 33 & 42 & 44 & 42 & 42 & 45 \\
\hline $10.001-20.000$ & 26 & 30 & 32 & 32 & 34 & 31 \\
\hline total & 143 & 133 & 128 & 123 & 124 & 126 \\
\hline
\end{tabular}


However, the total number of settlements was affected by a change in the criteria for their determination and the administrative status assigned to them. Until 1981, a set of indicators was used in determining the urban character of settlements, and later, only the legislative standard has been considered valid. Due to this, various settlements lost their status of municipal centers (Resavica, Vučje, Grdelica, Donji Milanovac, Mačvanska Mitrovica), while other settlements with a smaller population were granted the status of towns due to their developed functions (Arilje, Bač, Bački Petrovac, Bajina Bašta, Brus, Zlatibor, Ćićevac, Kosjerić, Lajkovac, Belanovica, Belo Polje, Titel, Tutin and Divčibare) or the status of a new municipal centre due to recent administrative changes (Surčin, Niš, Lapovo, Lajkovac, Niška Banja, Kostolac, Sremski Karlovci, Vranjska Banja). These events largely determined their further development and size. In the settlements that lost their status of towns or municipal centers, stagnation or decline in all spheres has been observed, while the newly established municipal centers experience expansion. On the other hand, the increase in the number of small towns in the modern period, especially in larger groups, is also determined by depopulation and the economic decline of some medium-sized towns, which are now in the category of small towns (Senta and Ćuprija). The population of small towns in Serbia, according to the last census (2011), accounts for $20 \%$ of the urban population and $11.9 \%$ of the total population of Serbia.

Regardless of the effects of the demographic and socio-economic transition, a significant growth has been achieved in this group of settlements. However, research shows that in the last inter-census period negative trends were recorded in 116 settlements, out of the total number of small towns in the Republic of Serbia (126). In urban centers (due to a smaller number of births and decreased migration), negative demographic trends are increasingly expressed and they are manifest in the process of depopulation, negative natural increase and an aging population. In the cause-and-effect circle of demographic processes, this leads to a more intense depopulation in these areas. The problems that small urban settlements in Serbia face today are the result of insufficiently controlled and directed processes of urbanization and an inadequate utilization of the existing network of settlements, developmental stagnation, and vulnerability of ecological, natural and urban environments. The basic problem of small urban settlements in Serbia is the stagnating and declining demographic vitality, which causes numerous individual problems in relation to larger urban areas. These processes determine the development and existence of small towns, and, consequently, the whole rural areas that they integrate.

\section{The role and evaluation of small towns}

The role of small towns, observed in this paper through their ranking and evaluation of the favorability of demographic conditions for development, determines their strength as a generator of development and a potential carrier of integration between rural and urban areas. A quantitative evaluation was carried out on the basis of demographic indicators and it has confirmed the hypothesis that the positive development of an urban area is affected, above all, by its functional and economic role in the settlement network. On the other hand, the evaluation of urban areas presented in this paper suggests that a revision of the status of urban settlements should be made.

Based on the demographic development small towns were grouped into five categories: very favorable, favorable, moderate, unfavorable, and extremely unfavorable. The rank of settlements was determined by the cumulative sum of ranks for chosen indicators (Annex). An evaluation of favorableness of demographic conditions was used as an additional criterion (Table 1). That was the platform for the classification of small towns. This indirectly highlights their role in the spatial and socio-economic integration of Serbia.

In the category of small towns with favorable conditions for development ten settlements are identified. According to the 2011 Census, 123,084 inhabitants lived in these ten towns. A half of these towns are located in the region of Vojvodina (Temerin, Futog, Sremska Kamenica, Petrovaradin and Beočin), two are located in the region of Belgrade (Surčin and Ovča), while only three settlements can be found in the rest of Serbia (Kostolac, Ub and Požega) (Figure 2). The difference in the functional character of small towns in Serbia is reflected in the group of 
settlements with very favorable conditions. On the one hand, this group of small towns includes suburbs, the so-called satellite towns, or, in other words, settlements that act as sources of commuting to large urban centers. With regard to this, gravitational zones of Novi Sad and Belgrade are particularly prominent, as the two most intensive daily urban systems in Serbia. In addition, in the mentioned daily urban systems settlements with self-developed functions are identified, but they still have a significant share of commuters in the opposite direction in their interaction with large centers (Beočin, Temerin). On the other hand, this group also includes functionally independent settlements that have a prominent position in connecting urban and rural areas, a good transport accessibility, and their own gravitational zones (Kostolac, Požega). Although they develop as a considerably large population group in the immediate vicinity of large cities, their role is very important in connecting urban areas that have a dense population and concentration of functions with other parts of the country. In this way, they act as the first bridge, i.e. the first level of connections, and the counterbalance to big cities and their dominance in the surrounding rural area.

A significantly greater number of settlements fall into the category of small towns with favorable conditions for development. They form a group of 46 small towns, with 406,613 inhabitants, and an average of 8,839 per settlement. Therefore, this group is more heterogeneous. These towns are distributed throughout the territory of the Republic, but in eastern part of Serbia their concentration is lower than in other parts of the country (Figure 2). This category also includes a significant share of satellite settlements within the gravitational zone of the capital. There are settlements that lack developed functions and are small in terms of population size, but still have a significant increase in population and a large share of commuters (Pinosava, Beli Potok, Bački Jarak, Palić, Sremski Karlovci, etc.). Five out of the seven highest ranked small towns with favorable conditions for development fall into this group of settlements (Dobanovci, Ostružnica, Pinosava, Beli Potok and Opovo). An important role is also played by settlements with an extremely favorable age structure, or, in other words, with a higher share of young people. These are the settlements of Western Serbia, where the majority of the population are Muslims. However, they failed to enter a higher category because of the extremely low economic activity. There are quite many settlements that are functionally independent and have their own, developed gravitational zones. These are old municipal centers, located in the vicinity of major roads or in the area between two centers of a higher rank. A significant number of them are small urban settlements, municipal centers, which are located in the zone of a highway. As the functional autonomy of these settlements is greater than the functional autonomy of the previous group, analogous to a greater distance from dominant labor centers, their function as development generators and role in maintaining the population balance in the territory of Serbia is of great importance. In the mountain regions of Central Serbia, these small towns act as an important link between predominantly rural areas that have a mainly agrarian character, and urban areas which serve as administrative, industrial and service centers. Also, in terms of traffic and the geographical position of this group of small towns, they are becoming an important factor in mitigating peripheral and traffic isolation and shifting toward greater accesibility (Figure 2).

Numerically, the largest group in this categorization is the group of small urban areas with moderate conditions for development. In this group, there are 49 settlements, extremely heterogeneous in character, with a total population of 326,301 and an average of 6,659 inhabitants per settlement. They are dispersed throughout the territory of Serbia and show a different influence of the selected indicators. The role of the migration component in calculating the rank is smaller than in higher categories. Only one settlement from Belgrade's daily urban system falls into this group (Rucka). There are only three small towns that may be considered large in terms of population size (Knjaževac, Ćuprija and Trstenik). In addition to the small share of daily commuters, they are characterized by an extremely unfavorable age structure, and a small share of young people or a significant population decline, as e.g. Trstenik. Despite their less favorable demographic characteristics, many towns from this group still have a certain potential, which is very important in the local, rather than regional terms. A large number of small towns in this group are former industrial Centers in Serbia (Trstenik, Aleksandrovac, Majdanpek, Prijepolje, etc.), which lost their status due to the inability to adapt 
to the economic transition and gain an economic significance in the new context. The quality of living conditions is declining, which fosters out-migration. However, in spatial terms, these towns should still act as a link between rural and urban areas of higher rank, and they should not be ignored. In isolated areas, in terms of traffic, they are the last node and the only connection with important traffic routes (Figure 2).

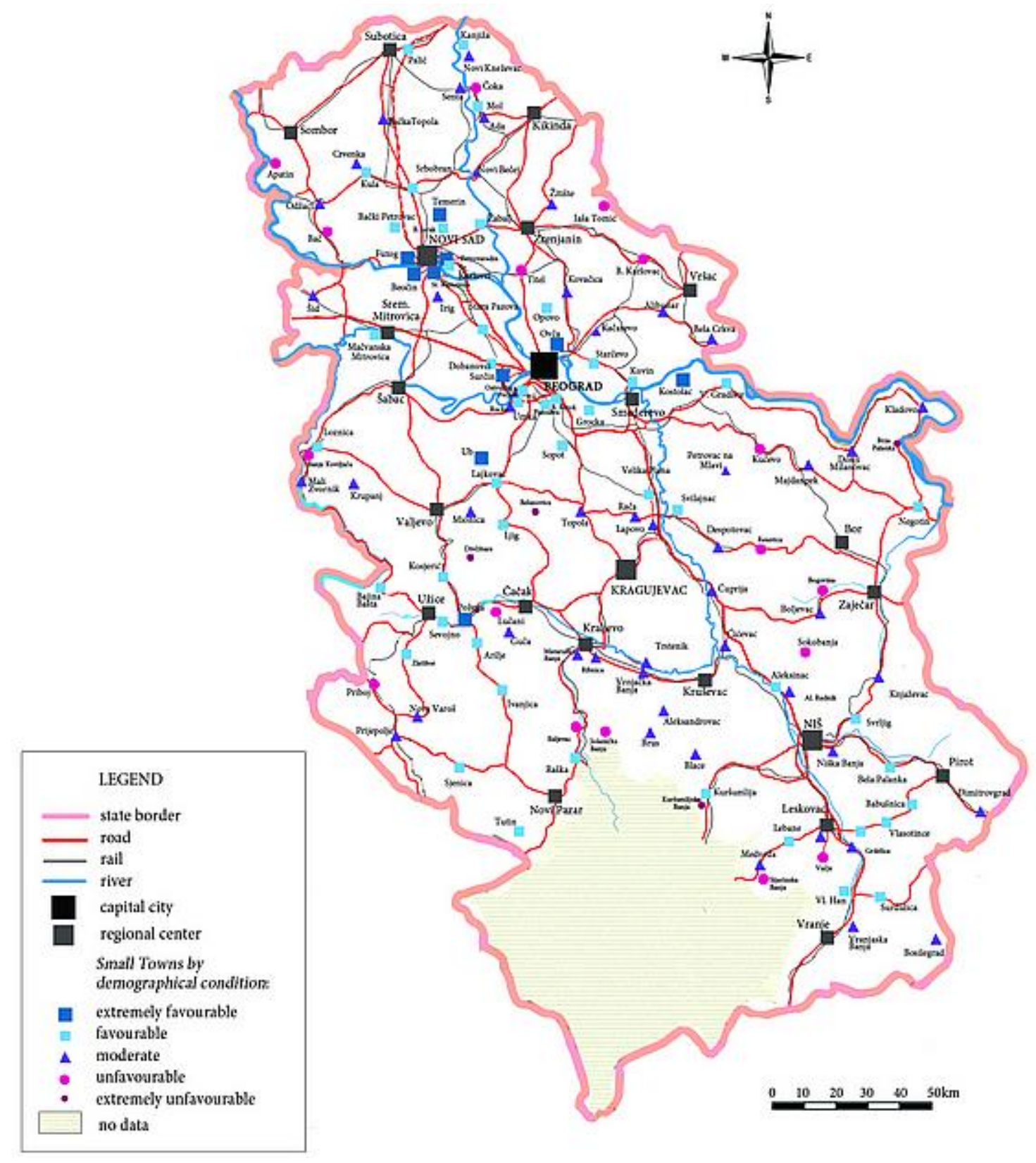

Fig 2. Small towns according to rank.

In the first category with unfavorable demographic characteristics, there are 17 settlements with a total population of 86,916 and an average of 4,936 per settlement. Mostly, these are extremely small settlements, with the exception of Apatin, which is classified in this category due to a rather small share of the young population, and Priboj, where a notable population decline can be observed. A negative demographic trend in these settlements is caused by the collapse of dominant industries, which were a generator of development of the region. On the other hand, this indicator has a different course in the case of Sokobanja and Baljevac, because of the specific functions developed in these settlements. The share of young people is proportionally low in all settlements in this category. Also, this category includes small towns with strong tourist functions, such as Jošanička Banja, Banja Koviljača and Sijarinska Banja that 
do not have the population strength to be categorized as favorable, but definitely record positive demographic trends. The role of the small towns from this group is purely local. Their significance is reflected in the integration of the surrounding rural area with the center of the municipality. In this respect, they are the weakest type of connection between the urban and the rural.

The last and the least attractive group is represented by small towns with extremely unfavorable conditions for development. Only four settlements (Belanovica, Brza Palanka, Kuršumlijska Banja and Divčibare) with a total population of 1,306 and an average of 327 per a settlement fall into this category. All of the four settlements are characterized by negative trends observed for all indicators. They are small in population size and have a negative demographic trend, as well as an unfavorable age structure and a small share of the young population. With the exception of Belanovica, all other settlements show a low level of economic activity. The daily circulation of the population is minimal, except for Kuršumlijska Banja, which developed in the immediate vicinity of a center of a higher rank and is totally dependent on it. All of these settlements are located in the southern part of Serbia, and compared to the most of the surveyed towns, they are fairly isolated geographically and traffic-wise (Figure 2). They are isolated urban centers, without administrative functions. Specifically, 13 out of the 16 lowest ranked towns are not municipal centers. As these towns are rather functionally dependent and are small settlements; they serve as secondary local centers. Development incentives in the rural environment are minimal and cannot play a greater role in connecting urban and rural areas.

\section{Conclusion and discussion}

Small towns are not a unified group and it is quite difficult to draw general conclusions. Several common characteristics are identified: they form a group of settlements that have less than 20,000 residents each; their urban character is defined based on statistical and legislative criteria; they have the status of a municipal center or a secondary local center, a direct contact with the rural environment and, as the most important characteristic, they have a role of the generate development and spread urban impulses towards surrounding rural areas.

However, clear differences between small towns are defined, which can be used for the gradation of their impact in connecting urban and rural areas, or bridging the differences between two opposing spatial categories. The greatest significance is ascribed to functionally independent settlements with favorable demographic conditions for development which are located at various distances from major regional centers and show a varying level of dependence on them. The second and very important rank was assigned to settlements with moderately favorable demographic conditions for regional and balanced spatial development which constitute an important link between the local and regional environment and provide a significant development impulse to the surrounding rural areas. The third rank was given to settlements that act as developmental and traffic 'islands' in a rural area and the local development cores, while the last two groups of small towns with unfavorable demographic features are considered to be irrelevant in linking the urban and the rural.

Based on the results, it can be concluded that demographic conditions in small towns in Serbia are better than the national average. In accordance with the role of small towns in the balanced regional, population and polycentric spatial development of Serbia, it is necessary to observe them from two perspectives. On the one hand, they are satellite settlements, formed in a planned or unplanned manner in the vicinity of major urban centers, taking advantage of infrastructure accessibility, the availability of public services and their hierarchical level in a settlement network. The settlements that were formed in this way have various spatial and demographic origins and they include settlements that had a satellite role before the monitored period, as well as settlements that have become satellites during modern processes. On the other hand, some settlements have established themselves as urban centers with a smaller degree of dependence in demographic and in functional terms. Unlike the first group of small towns, which rely on the proximity of a large urban center, these settlements mainly took shape in rural environments and they act as the functional core of a wider area. Also, historically, these settlements are characterized by a significantly more complex genesis than the first group; 
the unifying factor is their role in relation to rural areas. Whether they are located close to major urban centers or are themselves the dominant urban centers within a territory, one of their most significant roles is to reduce the degree of spatial and functional periphery of rural areas, or, in other words, they play an important role as links between rural and urban areas and enable an easier access to the basic functions for the rural population.

In regional terms, small towns in the southwestern part of the country record a population growth based on the components of natural increase (Sjenica, Tutin, Nova Varoš). On the other hand, towns with tourist function show a population growth based on migration components (Zlatibor, Vrnjacka Banja, Sokobanja, etc.). The region of Belgrade certainly has the most intense impact on its metropolitan area, where the process of urbanization and industrialization is very strong and where a large number of small towns were eventually formed (20) whose functions are marked by the domination of the metropolitan area. Also, Novi Sad has had a significant influence on the formation of a network of small towns in its vicinity, thanks to the infrastructure accessibility and spatial endowment, as well as an inherited network of settlements on the territory of Vojvodina are one of the greatest advantages for the development of small towns. On the other hand, the Region of Eastern and Southern Serbia faces the most of the limiting factors for the development of a network of small towns. Geographical areas with a lower degree of accessibility, which have a functionally peripheral character, along with traditional demographic problems, have led to negative conditions for the general development of small towns in the observed areas. The functions of small towns within zones exposed to an intensive influence of a large city are in many ways specific. Urban settlements without the status of municipal centers are formed in the gravitational area or within the administrative boundaries of larger towns and functional centers. Small towns with the function of municipal centers outside the area of the intense influence of larger towns have a more complex role and at the same time have to meet more difficult conditions in order to be recognized as development poles. A decreasing extent of communting from rural to urban area indicates that rural areas are exposed to the depopulation process or even a demographic exodus.

In fact, small towns should be the main generators of the demographic revitalization of Serbia, as well as the carriers of decentralization (Filipović \& Đurđević, 2007). They should play the role of major transmitters of the influence of dominant urban centers to rural environments. Because of their position, and historical inheritance, small towns act as the basic link or a bridge between urban and rural areas. The demographic revitalization and a balanced regional population development of Serbia require a huge economic investment and an accelerated development of less developed areas. It is also necessary to define an explicit population policy and implement it consistently.

\section{Acknowledgments}

This paper is a part of scientific project 47007 supported by the Ministry of Education, Science and Technological Development of the Republic of Serbia.

References

[1] Ban, M. (1970). Naselja u Srbiji i njihov razvoj u periodu 1948 - 1961. Belgrade: Institute of Social Sciences, Demographic Research Center.

[2] Bandaranaike, S. (2002). Small towns can make a difference (pp. 1-43). In 2020 vision: Australia's demographic future: Australian Population Association $11^{\text {th }}$ Biennial Conference. Sydney: Australian Population Association.

[3] Bukurov, B. (1980). Problem određivanja gradskih naselja u Vojvodini (pp. 51-61). Collection of papers Geographical Institute "Jovan Cvijić" SASA, 32. 
[4] Cvijić, J. (2000). Balkansko poluostrvo. Belgrade: Serbian Academy of Science and Arts and Institute for textbooks and teaching aids.

[5] Djordjević, T. (1924). Iz Srbije kneza Miloša - stanovništvo i naselja. Belgrade: Izdavačka knjižarica GeceKon.

[6] ESPON 1.4.1(2006). The Role of Small and Medium-Sized Towns. Wien: Austrian Institute for Regional Studies and Spatial Planning.

[7] Filipović, M., \& Đurđević, J. (2007). Demografske promene u gradovima Centralne Srbije komparativna analiza. Arhitektura i urbanizam 20-21, 101-111.

[8] Ginić, (1967). Dynamics and structure of the urban population of Yugoslavia. Belgrade: Institute of Social Sciences.

[9] Grgurević, O. (1995). Prilog proucavanju postupka demografskog vrednovanja naselja. Prostor, Vol. 3:2(10), 217-232.

[10] Grgurevič, O. (2001). Prilog proučavanju postupka demografskog vrednovanja naselja. Prostor, 3(2), 217-232.

[11] Kenyon, P. \& Black, A., eds. (2001). Small Town Renewal. RIRDC Publication No 1/043. Canberra: Union Offset.

[12] Kojić, B. (1970). Varošice u Srbiji XIX veka - regionalno urbanistička studija. Belgrade: Institute of urbanism and architecture of Serbia.

[13] Kojić, B. \& Simonović, Dj. (1971). Seoska naselja Srbije. Belgrade: ICS.

[14] Kojić, B. (1973). Sistematizacija naselja. Belgrade: Institute of architecture and urbanism in Serbia.

[15] Kokotović, V. \& Spalević, A. (2014). Demographic and functional evaluation of urban areas in Vojvodina region. The Matica Srpska Journal of Social Sciences, 148, 593-605, DOI: 10.2298/ZMSDN1448593K.

[16] Kokotović, V., Filipović, M. \& Magdalenić, I. (2016). Internal mobility of Serbian population in the second half of the $X X$ and beginning of the XXI century. Bulletin of the Institute of Ethnography SASA XLIV, DOI: 10.2298/GEI151019005K.

[17] Marjanović-Uzelac (1999). Middle Towns - Myth or Reality? Društvena istraživanja, 8(1), 320.

[18] Macura, M. (1954). Kriterijum za razgraničenje gradskog i seoskog stanovništva. Статистичка ревија. Yugoslavian Society.

[19] OECD (1994). Creating rural indicators for shaping territorial policy. Paris.

[20] Pirisi, G. \& Trócsányi, A. (2006). Demographic trends in Hungary at the twin of the millennium, The Matica Srpska Journal of Social Sciences, 121, 465-479.

[21] Pirisi, G. \& Trócsányi, A. (2007). Demographic processes in Hungary and their manifestation in small towns. Romanian Review of Regional Studies, 3(2), 73-82.

[22] Petovar, K. (2007). O kriterijumima definicije grada (pp. 83-95). In Milenković, D. \& Damjanović, D., eds. Towards a new status of urban settlements in Serbia. Beograd: Palgo Centar.

[23] Radovanović, M. (1970). Značaj istorijsko-geografskih faktora za genezu i sistematizaciju naselja u Srbiji (pp. 94-95). Collection of papers Faculty of Natural Sciences and Mathematic 17. Beograd: University of Belgrade.

[24] Spasić, N. (1984). Small towns in Serbia. Belgrade: Institute of Architecture and Urban \& Spatial Planning of Serbia. 
[25] Spasić, N., Petrić, J. \& Filipović, M. (2007). Demographic changes in towns of Central Serbia - Comparative analysis. Arhitektura i urbanizam, Belgrade: Institute of Architecture and Urban \& Spatial Planning of Serbia (IAUS).

[26] SPRS (2010). Spatial Plan of the Republic of Serbia, 2010/2014/2021. Official Gazette No. $24 / 10$.

[27] Stamenković, S. \& Bacević, M. (1992). Geografija naselja. Belgrade: Faculty of Geography.

[28] Stamenković, S. (2004). Neka aktuelna pitanja prostorne organizacije mreže naselja i relevantni demografski problem u Srbiji. Demography, 1, 115-135.

[29] Stojanović, (1984). Small towns in Serbia. Belgrade: Institute of Architecture and Urban \& Spatial Planning of Serbia.

[30] Stojanović, B. \& Vojković, G. (2005). Urban Agglomerations on Main Development Axes as Poles of Demographic Revitalization of Serbia. Stanovništvo, 43(1-4), 61-79, DOI: 10.2298/STNV0504061S.

[31] Tošić, B. (1996). Typology of settlements based on applied researches (in Serbian). Collection of papers Geographical Institute "Jovan Cvijić" SASA, Vol. 46, 143-149.

[32] Tošić, D. (1999). Prostorno-funkcijski odnosi i veze u nodalnoj regiji Užica [unpublished PhD thesis]. Belgrade: Faculty of Geography.

[33] Veljković, A., Jovanović, R. \& Tošić, B. (1995). Gradovi Srbije - centri razvoja u mreži naselja. Special Issue 44. Belgrade: Geographical Institute "Jovan Cvijic" SASA.

[34] Živanović, Z. (2012). Uloga gradova srednje veličine u ravnomernom regionalnom razvoju centralne Srbije [unpublished PhD thesis]. Belgrade: Faculty of Geography. 


\section{Annex}

Evaluation of small towns according to qualitative and quantitative research methodology

\begin{tabular}{|c|c|c|c|c|c|c|c|}
\hline \multirow[t]{2}{*}{ classes } & \multirow{2}{*}{\begin{tabular}{|l|} 
Sum of \\
ranks
\end{tabular}} & \multirow[t]{2}{*}{ Urban settlement } & \multicolumn{5}{|c|}{ Qualitative approach } \\
\hline & & & $\begin{array}{c}\text { Total } \\
\text { population }\end{array}$ & $\begin{array}{c}\text { Index of } \\
\text { population } \\
\text { change }\end{array}$ & Youth 0-19 & $\begin{array}{l}\text { Employed } \\
\text { population }\end{array}$ & $\begin{array}{c}\text { Daily } \\
\text { migration }\end{array}$ \\
\hline \multirow{10}{*}{$\begin{array}{c}\text { extremly } \\
\text { favourable }\end{array}$} & 117 & Surčin & 5 & 5 & 3 & 4 & 4 \\
\hline & 136 & Temerin & 5 & 5 & 3 & 4 & 3 \\
\hline & 138 & Futog & 5 & 5 & 3 & 4 & 4 \\
\hline & 151 & Sremska Kamenica & 4 & 5 & 3 & 4 & 4 \\
\hline & 152 & Ovča & 2 & 5 & 3 & 4 & 4 \\
\hline & 162 & Petrovaradin & 4 & 5 & 2 & 4 & 4 \\
\hline & 167 & Kostolac & 3 & 5 & 4 & 4 & 3 \\
\hline & 190 & Beočin & 3 & 4 & 3 & 4 & 3 \\
\hline & 195 & $\mathrm{Ub}$ & 3 & 5 & 3 & 4 & 3 \\
\hline & 197 & Požega & 4 & 4 & 3 & 4 & 2 \\
\hline \multirow[t]{31}{*}{ favourable } & 204 & Dobanovci & 3 & 5 & 2 & 4 & 4 \\
\hline & 209 & Raška & 3 & 4 & 3 & 4 & 3 \\
\hline & 210 & Ostružnica & 2 & 5 & 2 & 4 & 4 \\
\hline & 210 & Pinosava & 2 & 5 & 3 & 4 & 5 \\
\hline & 211 & Opovo & 2 & 4 & 3 & 4 & 4 \\
\hline & 219 & Arilje & 3 & 5 & 3 & 4 & 2 \\
\hline & 220 & Beli Potok & 2 & 5 & 2 & 4 & 4 \\
\hline & 220 & Vladičin Han & 3 & 4 & 3 & 4 & 3 \\
\hline & 221 & Velika Plana & 5 & 4 & 3 & 4 & 2 \\
\hline & 224 & Stara Pazova & 5 & 4 & 3 & 4 & 3 \\
\hline & 228 & Kuršumlija & 4 & 4 & 3 & 4 & 2 \\
\hline & 232 & Ivanjica & 4 & 4 & 3 & 5 & 2 \\
\hline & 233 & Starčevo & 3 & 4 & 3 & 4 & 4 \\
\hline & 234 & Negotin & 5 & 4 & 3 & 4 & 2 \\
\hline & 236 & Grocka & 3 & 5 & 2 & 4 & 3 \\
\hline & 237 & Zlatibor & 2 & 5 & 2 & 5 & 3 \\
\hline & 238 & Ljig & 2 & 5 & 3 & 4 & 2 \\
\hline & 239 & Žabalj & 3 & 4 & 3 & 4 & 3 \\
\hline & 242 & Bački Jarak & 3 & 4 & 3 & 4 & 4 \\
\hline & 245 & Sevojno & 3 & 4 & 2 & 4 & 3 \\
\hline & 246 & Bajina Bašta & 3 & 4 & 3 & 4 & 2 \\
\hline & 248 & Surdulica & 4 & 4 & 3 & 4 & 2 \\
\hline & 253 & Bela Palanka & 3 & 4 & 3 & 4 & 3 \\
\hline & 254 & Sjenica & 4 & 5 & 4 & 3 & 2 \\
\hline & 257 & Kanjiža & 3 & 4 & 2 & 4 & 2 \\
\hline & 258 & Lebane & 3 & 4 & 3 & 4 & 2 \\
\hline & 260 & Palić & 3 & 5 & 2 & 4 & 4 \\
\hline & 261 & Aleksinac & 5 & 4 & 3 & 4 & 3 \\
\hline & 262 & Vlasotince & 5 & 4 & 3 & 4 & 2 \\
\hline & 265 & Veliko Gradište & 3 & 5 & 3 & 4 & 1 \\
\hline & 268 & Sremski Karlovci & 3 & 4 & 2 & 4 & 4 \\
\hline
\end{tabular}




\begin{tabular}{|c|c|c|c|c|c|c|c|}
\hline & 269 & Loznica & 5 & 4 & 3 & 4 & 2 \\
\hline & 272 & Tutin & 4 & 5 & 5 & 1 & 2 \\
\hline & 275 & Srbobran & 4 & 4 & 3 & 4 & 3 \\
\hline & 276 & Umka & 3 & 4 & 3 & 4 & 4 \\
\hline & 279 & Mol & 3 & 3 & 3 & 4 & 3 \\
\hline & 280 & Sopot & 1 & 5 & 3 & 4 & 3 \\
\hline & 284 & Babušnica & 2 & 5 & 2 & 4 & 2 \\
\hline & 287 & Kosjerić & 2 & 4 & 3 & 4 & 2 \\
\hline & 288 & Kovin & 4 & 4 & 2 & 4 & 3 \\
\hline & 290 & $\begin{array}{l}\text { Mačvanska } \\
\text { Mitrovica }\end{array}$ & 2 & 4 & 3 & 3 & 4 \\
\hline & 291 & Kula & 5 & 4 & 3 & 4 & 3 \\
\hline & 292 & Bački Petrovac & 3 & 4 & 3 & 4 & 3 \\
\hline & 297 & Lajkovac & 2 & 4 & 2 & 4 & 3 \\
\hline & 297 & Svrljig & 3 & 4 & 2 & 4 & 2 \\
\hline & 299 & Svilajnac & 3 & 4 & 3 & 4 & 1 \\
\hline moderate & 306 & Senta & 5 & 4 & 2 & 4 & 2 \\
\hline & 307 & Brus & 2 & 4 & 3 & 4 & 2 \\
\hline & 309 & Petrovac na Mlavi & 3 & 4 & 3 & 4 & 2 \\
\hline & 311 & Aleksandrovac & 3 & 4 & 3 & 4 & 2 \\
\hline & 313 & Vranjska Banja & 3 & 4 & 3 & 3 & 3 \\
\hline & 314 & Rucka & 1 & 5 & 2 & 4 & 5 \\
\hline & 317 & Knjaževac & 5 & 4 & 2 & 4 & 2 \\
\hline & 317 & Mataruška Banja & 2 & 5 & 2 & 4 & 4 \\
\hline & 317 & Pećani & 1 & 5 & 2 & 4 & 5 \\
\hline & 319 & Medvedja & 2 & 5 & 4 & 4 & 2 \\
\hline & 320 & Vrnjačka Banja & 4 & 5 & 2 & 4 & 2 \\
\hline & 323 & Kačarevo & 3 & 4 & 3 & 4 & 4 \\
\hline & 324 & Ćićevac & 2 & 4 & 2 & 4 & 3 \\
\hline & 324 & Novi Bečej & 4 & 4 & 3 & 4 & 2 \\
\hline & 327 & Novi Kneževac & 3 & 4 & 2 & 4 & 3 \\
\hline & 328 & Bosilegrad & 2 & 4 & 3 & 4 & 1 \\
\hline & 330 & Krupanj & 2 & 4 & 3 & 4 & 2 \\
\hline & 333 & Niška Banja & 2 & 4 & 2 & 4 & 4 \\
\hline & 336 & Trstenik & 5 & 3 & 2 & 4 & 2 \\
\hline & 338 & Kladovo & 3 & 4 & 2 & 4 & 1 \\
\hline & 342 & Bačka Topola & 4 & 4 & 2 & 4 & 2 \\
\hline & 344 & Ćuprija & 5 & 4 & 2 & 4 & 2 \\
\hline & 347 & Blace & 3 & 4 & 3 & 3 & 2 \\
\hline & 350 & Mali Zvornik & 2 & 4 & 3 & 4 & 2 \\
\hline & 351 & Šid & 4 & 4 & 3 & 4 & 2 \\
\hline & 358 & Ada & 3 & 4 & 2 & 4 & 2 \\
\hline & 360 & Žitište & 2 & 3 & 3 & 4 & 3 \\
\hline & 363 & Prijepolje & 4 & 3 & 3 & 4 & 1 \\
\hline & 365 & Lapovo & 3 & 4 & 2 & 4 & 2 \\
\hline & 368 & Mionica & 1 & 4 & 2 & 4 & 3 \\
\hline & 369 & Kovačica & 3 & 4 & 2 & 4 & 3 \\
\hline
\end{tabular}




\begin{tabular}{|c|c|c|c|c|c|c|c|}
\hline & 370 & Alibunar & 2 & 3 & 2 & 4 & 3 \\
\hline & 371 & Crvenka & 3 & 3 & 3 & 3 & 3 \\
\hline & 371 & Odžaci & 3 & 3 & 2 & 4 & 2 \\
\hline & 376 & Nova Varoš & 3 & 3 & 3 & 4 & 2 \\
\hline & 376 & Rača & 2 & 4 & 3 & 4 & 2 \\
\hline & 377 & Aleksinački Rudnik & 1 & 3 & 3 & 4 & 4 \\
\hline & 381 & Boljevac & 2 & 3 & 3 & 4 & 2 \\
\hline & 383 & Grdelica & 2 & 3 & 3 & 2 & 3 \\
\hline & 383 & Topola & 2 & 4 & 2 & 4 & 2 \\
\hline & 385 & Donji Milanovac & 2 & 2 & 2 & 5 & 2 \\
\hline & 390 & Ribnica & 1 & 1 & 3 & 3 & 4 \\
\hline & 393 & Irig & 2 & 4 & 2 & 3 & 3 \\
\hline & 395 & Bela Crkva & 3 & 3 & 3 & 4 & 2 \\
\hline & 395 & Majdanpek & 3 & 2 & 2 & 5 & 1 \\
\hline & 396 & Despotovac & 2 & 4 & 2 & 4 & 2 \\
\hline & 398 & Guča & 1 & 3 & 2 & 4 & 3 \\
\hline & 399 & Belo Polje & 1 & 4 & 2 & 4 & 4 \\
\hline & 399 & Dimitrovgrad & 3 & 4 & 2 & 4 & 2 \\
\hline unfavourable & 400 & Apatin & 5 & 4 & 2 & 4 & 2 \\
\hline & 404 & Bač & 3 & 3 & 2 & 4 & 3 \\
\hline & 415 & Jošanička Banja & 1 & 3 & 3 & 3 & 3 \\
\hline & 415 & Lučani & 2 & 2 & 2 & 4 & 3 \\
\hline & 417 & Titel & 3 & 3 & 2 & 4 & 3 \\
\hline & 421 & Bogovina & 1 & 3 & 3 & 3 & 3 \\
\hline & 421 & Sokobanja & 3 & 4 & 2 & 4 & 2 \\
\hline & 423 & Banja Koviljača & 3 & 3 & 2 & 3 & 3 \\
\hline & 424 & Baljevac & 1 & 4 & 2 & 4 & 3 \\
\hline & 424 & Banatski Karlovac & 3 & 3 & 2 & 4 & 3 \\
\hline & 434 & Resavica & 2 & 3 & 3 & 4 & 2 \\
\hline & 435 & Sijarinska Banja & 1 & 1 & 3 & 3 & 3 \\
\hline & 444 & Čoka & 2 & 3 & 2 & 4 & 3 \\
\hline & 458 & Priboj & 4 & 2 & 2 & 3 & 1 \\
\hline & 476 & Vučje & 2 & 3 & 2 & 3 & 3 \\
\hline & 477 & Kučevo & 2 & 3 & 2 & 4 & 1 \\
\hline & 492 & Jaša Tomić & 2 & 2 & 2 & 4 & 3 \\
\hline extremly & 514 & Belanovica & 1 & 2 & 2 & 4 & 2 \\
\hline & 515 & Brza Palanka & 1 & 2 & 2 & 3 & 3 \\
\hline & 516 & Kuršumlijska Banja & 1 & 2 & 1 & 2 & 4 \\
\hline & 587 & Divčibare & 1 & 1 & 1 & 2 & 2 \\
\hline
\end{tabular}

\section{Sources:}

Statistical Office of the Republic of Serbia (2012a). Census of Population, Households and Dwellings, 2011, Comparative review of the number of population 1948, 1953, 1961, 1971, 1981, 1991, 2002 and 2011, book No.20, Belgrade

Statistical Office of the Republic of Serbia (2012b). Census of Population, Households and Dwellings, 2011, Age and sex, book No.2, Belgrade

Statistical Office of the Republic of Serbia (2012c). Census of Population, Households and Dwellings, 2011, Economic activity, book No.7, Belgrade 